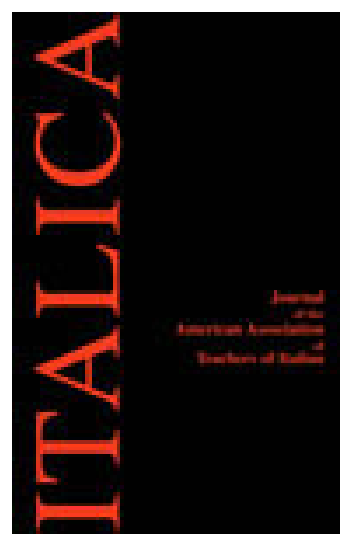

The Pathways of Knowledge in Boiardo and Ariosto: The Case of Rodamonte Author(s): Jo Ann Cavallo

Source: Italica, Vol. 79, No. 3 (Autumn, 2002), pp. 305-320

Published by: American Association of Teachers of Italian

Stable URL: http://www.jstor.org/stable/3656094

Accessed: 24/04/2014 10:44

Your use of the JSTOR archive indicates your acceptance of the Terms \& Conditions of Use, available at http://www.jstor.org/page/info/about/policies/terms.jsp

JSTOR is a not-for-profit service that helps scholars, researchers, and students discover, use, and build upon a wide range of content in a trusted digital archive. We use information technology and tools to increase productivity and facilitate new forms of scholarship. For more information about JSTOR, please contact support@jstor.org. 


\section{The Pathways of Knowledge in Boiardo and Ariosto: The Case of Rodamonte}

"All men by nature desire to know." - Aristotle, Metaphysics

$\mathrm{H}^{\circ}$ ow do we come to know? What can be known? How can true knowledge be distinguished from belief and opinion? What are the effects of knowledge? How does knowledge shape the course of our actions? These are some of the questions that philosophers were asking in fifteenthand sixteenth-century Italy. The answers would have differed depending on whether one adhered to scholastic Aristotelianism, Neoplatonism, "nature philosophies," or Skepticism, but all schools of thought were engaged in discussions about the nature of knowledge. ${ }^{1}$ Philosophers, moreover, were not the only ones interested in the process of knowledge acquisition and the relation of knowledge to action. In this essay I focus on how the poets Matteo Maria Boiardo and Lodovico Ariosto develop their thoughts on the subject in their romance epics, Orlando innamorato and Orlando furioso. My intention is not to fit them into any particular philosophical movement (although correspondences will be noted when relevant), but rather to show that both poets were deeply aware of the questions surrounding the issue of knowledge and that they provided their own answers through their fiction.

Boiardo's Orlando innamorato presents a world in which characters are in dire need of greater knowledge about both themselves and the world around them, and assumes that such knowledge will lead to the betterment of the self and of society at large. In the Orlando furioso, Ariosto challenges Boiardo's optimistic faith in knowledge in two fundamental ways: first, he suggests that what is referred to as knowledge is often no more than unfounded belief bolstered by subjective emotional states; second, he shows that objective knowledge does not necessarily have positive consequences, but, on the contrary, can actually bring about the undoing of both the self and the social fabric. Boiardo had developed his conception of knowledge as the road to self-improvement most fully through the history of the Saracen Rodamonte. Ariosto uses the same character, renamed Rodomonte, transforming the knight's previously charted progress on the pathways of knowledge into an outright dead end. In both poems, the question "to know or not to know" is crucial because the stakes are so high. In essence, what you know determines how you act and therefore who you are. 
The principal epic matter of the Orlando innamorato begins with the council of African kings in Biserta that opens Book 2. After King Agramante has announced his ambitious plan to invade France, the other kings respond. Branzardo, held to be the most prudent ("il più prudente," OI 2.1.38) of all those gathered at Biserta, is the first to speak. ${ }^{2}$ Turning a problem of action (whether or not to invade France) into a question of knowledge, he states that there are three ways to arrive at knowledge of all things - reason, example, and experience:

Tutte le cose de che se ha scienza,

$O$ ver che son provate per ragione,

O per esempio, o per esperienza. (OI 2.1.39)

The statement takes on the aspect of a lesson when Branzardo goes on to illustrate each of these three ways in three distinct stanzas. His three pathways of knowledge, moreover, all lead to the same conclusion - that the proposed invasion of France would end in failure. King Sobrino next speaks up to support Branzardo's argument based on experience, since he has fought the same Christian knights during the invasion of France led by Agramante's grandfather ("io gli ho provati," OI 2.1.51). ${ }^{3}$ The fact that Boiardo singles out Branzardo as a figure of wisdom ("ha molto sapere," OI 2.1.44) suggests a close alliance between prudence and wisdom as the virtues that permit us to foresee the probable outcome of our actions and therefore help us to make the right choices. ${ }^{4}$

Boiardo's fictional alliance between wisdom and prudence recalls the moral philosophy of Aristotle which, along with the writings of Cicero and Seneca, helped shape the idea of wisdom in fifteenth century civic humanism. In the Nicomachean Ethics, Aristotle related wisdom to prudence, which he defined as "something more than a knowledge of general principles," to become rather "a matter of conduct" (180)..$^{5}$ In his study of the Renaissance idea of wisdom, Eugene Rice examines the humanists' understanding of wisdom as an active, not contemplative virtue, as an ethical precept rather than a body of knowledge (149). Regarding Coluccio Salutati, Rice remarks that "the only reason he does not say that prudence is nobler than wisdom is that he is prepared to take a further step and, by defining wisdom as moral philosophy, identify the two" (36). ${ }^{6}$

The arrogant Rodamonte begins his refutation of the two previous interventions with recourse to a "truth" based on scientific observation: "In ciascun loco / Ove fiamma s'accende, un tempo dura / piccola prima, e poi si fa gran foco; / ma come viene al fin, sempre se oscura, / mancando del suo lume a poco a poco" (OI 2.1.53). This scientific fact is the basis of an analogy that describes human nature: "E così fa l'umana creatura, / che, poi che la di sua età passato il verde, / la vista, il senno e l'animo si perde" (OI 2.1.53). Using facts about the world of nature in order to explain 
human behavior was common practice at least as far back as Aristotle, and was based on the understanding of correspondences between man (the microcosm) and the greater world around him (the macrocosm). The particular example that Rodamonte provides, moreover, deals with the concepts of light and vision. He measures the flame by the light (lume) that it provides and by its darkening (se oscura). On the human front, the listing of sight (vista), sense/wisdom (senno) and courage/spirit (animo), suggests a chronological sequence: sight leads to knowledge which then governs action. The primacy of sight in Rodamonte's analogy continues as he applies his universal statement regarding humankind to the circumstances at hand: "Questo ben chiar si vede nel presente / per questi duo che adesso hanno parlato" (OI 2.1.54). Rodamonte is adept at applying scientific knowledge to human nature and at moving from the universal to the particular, and his emphasis on sight is a clue that for him the underlying basis of all knowledge is sense-perception. Indeed, as I argue below, Rodamonte will later state that his own knowledge of the world is based on what he can see with his eyes. One could thus say that Rodamonte counters the moral philosophical tradition with scientific observation of natural phenomena and human nature, replacing "experience, example, and reason" with "sight" as the privileged mode of knowledge acquisition. However, despite Rodamonte's recourse to the rigors of science, the limits of sense-perception for gaining knowledge were pointed out at least as far back as Plato's Theaetetus, in which Socrates criticized those "who believe in nothing but what they can grasp in their hands, and who will not allow that actions or generation or anything invisible can have real existence." 7

The King of Garamanta intervenes next to suggest another way of arriving at knowledge - divine revelation. A prophet of the Muslim divinity Apollino, the King of Garamanta is described as a "saggio [. . . ] incantatore, astrologo e indovino" (OI 2.1.57). Whereas Branzardo and Sobrino sought knowledge through moral philosophy, and Rodamonte sought knowledge through earth science, the King of Garamanta seeks knowledge through metaphysics, and we are told that he spends his time counting the stars and measuring the heavens. Divine revelation leads him to the same conclusion that the other two kings had arrived at through prudence and wisdom, and he goes beyond their vision by adding a detail that the others could not have foreseen: "E Rodamonte con sua gran possanza / Diverrà pasto de' corbi de Franza" (OI 2.1.59). If Rodamonte dismissed prudence and wisdom, one can well imagine how he responds to prophecy. He declares that he will be his own prophet in France ("io serò il profeta di quel loco," OI 2.1.61), thus asserting his unlimited faith in his ability to fashion his own destiny.

Although the subject is ostensibly about a proposed war in France, the three-way discussion suggests a battle pitting prudence, wisdom, and 
divine revelation against sensory perception. In addition, the kings' wider knowledge of the past, the world, and the heavens, is contrasted with Rodamonte's declared knowledge of his own strength. Their differing conceptions of knowledge acquisition lead them to make opposite assessments about the outcome of an African invasion of France: while the three kings predict disaster, Rodamonte expects victory. Boiardo had already indicated that Biserta would be destroyed in the upcoming war (2.1.19), thus confirming in advance that the kings were correct.

One could also place these pathways of knowledge in a hierarchical relationship. Aristotle postulated that knowledge originates - but does not end - with sense-perception, and mainstream medieval and Renaissance philosophers commonly reiterated that view. In his speculative works, the philosopher and theologian Nicholas Cusano (1401-1464) outlined a trajectory of knowledge acquisition which moved from sense-perception to the higher faculties of reason and intellect. ${ }^{8}$ Yet Cusano believed that even knowledge attained by discursive reason was no more than an approximation or a conjecture, and, especially in the quest to know God, the intellect needed to be supplemented with religious faith. In this context, one could say that Rodamonte is stuck on the first rung of the ladder of knowledge, while Branzardo, Sobrino and the King of Garamanta symbolize the successive stages.

King Agramante, characterized by pride, arrogance, and ambition, intervenes to tell the gathering of kings that they must accompany him to France. He does not, however, rely exclusively on sense-perception the way that Rodamonte does. When the King of Garamanta reveals that a young man who could bring down Charlemagne is hidden out of sight in the mountains, Agramante believes his words ("ben crede a sue parole") and decides to delay the invasion until the youth is found. Boiardo endorses Agramante's decision by confirming the King of Garamanta's past success: “E sempre nel passato avea veduto / Il corso delle stelle tutte quante, / E sempre avanti il tempo predicia / Divizia, guerra, pace, carestia" (OI 2.1.76). Here the King of Garamanta is not only predicting the future (the outcome of the war), but he is also affirming the existence of something (or, in this case, someone) not yet verified by sensory perception. The search could thus be seen as a contest between the King of Garamanta's and Rodamonte's opposing theories of knowledge acquisition.

The subsequent failure of the search for the youth, Rugiero, leads to a discussion that centers once again on the problem of knowledge. King Mulabuferso, sent to find Rugiero on Mount Carena, affirms and swears that Rugiero is not there simply because he has not seen him:

Visto ho l'ultimo dì quel che il primiero.

Onde io te acerto e affermo in iuramento,

Che là non se ritrova alcun Rugiero. (OI 2.3.18) 
The first verse begins with what Mulabuferso has actually seen ("visto ho"), the second contains two verbs which confer the certainty of knowledge in a legal context ("acerto e affermo in iuramento"), while the third verse categorically states the absence of Rugiero. Following this parody of logical deduction, Mulabuferso states his belief that the Rugiero they are seeking never even existed: "Né altro credo io che sia più nato mai" (OI 2.3.18). Mulabuferso's reasoning is quite simple, even if erroneous: since he, like Rodamonte, believes only what he sees, he assumes that whatever he does not see cannot exist. Rodamonte then turns Mulabuferso's statement of belief in the non-existence of Rugiero into a general maxim, cursing any man who believes what he has not seen: "Mal aggia l'omo che dà tanta fede / Al ditto di altri e a quel che non si vede!" (OI 2.3.20). Continuing the link between sight, knowledge, and existence, Rodamonte then shifts from the dubious existence of Rugiero to that of the gods: "Se egli è alcun dio nel cel, ch'io nol so certo" (OI 2.3.22). Although Rodamonte expressly negates the possibility of knowing whether God exists or not ("io nol so certo"), he again assumes that sight is the only way to acquire such knowledge: "Omo non è che l'abbia visto esperto" (OI 2.3.22). He then goes on to conclude that belief in God is based on human emotion; in this case, fear: "Ma la vil gente crede per paura" (OI 2.3.22).

Rodamonte's refusal to give credence to what another says ("al ditto di altri") leaves him with a view of the world limited to what he has seen with his own eyes. In the space of this restricted world, he has faith exclusively in his weapons and himself:

Io de mia fede vi ragiono aperto

Che solo il mio bon brando e l'armatura

E la maza ch'io porto e 'l destrier mio

E l'animo ch'io ho, sono il mio dio. (OI 2.3.22)

This is not man fashioned in the image of God, but man as a god unto himself. He is the center of a universe that revolves around him. After hearing Rodamonte's reductionist view of reality, the King of Garamanta reaffirms his ability to discern and convey truth ("il vero"), a truth which for him includes the existence of God. He attributes Rodamonte's attitude precisely to a faulty manner of seeing, and his answer plays with the notion of sight: "Come vedeti, egli ha il viso perduto / Benché mai tutto non l'avesse intiero" (OI 2.3.25). As Bruscagli notes, il viso refers to la vista or, in this case, discernment, thus referring to Rodamonte's inability to see with the mind's eye (vol. 2: 574). At the same time, by prefacing his remark to Agramante with "come vedeti," the King of Garamanta calls on Agramante to share his mode of seeing in opposition to Rodamonte's impaired vision. Agramante once again sides with the King of Garamanta against Rodamonte, and decides to continue searching for Rugiero. Rodamonte, 
by contrast, refuses to wait any longer and immediately crosses the sea to France. Although he considered himself his own god, he is powerless against the forces of fortune, and a storm at sea leads to the loss of two thirds of his men before he even steps ashore onto French territory.

Once Rodamonte comes into contact with the world outside Africa, he begins to reassess his knowledge of his place in it. ${ }^{9} \mathrm{~A}$ preliminary step in Rodamonte's road to greater knowledge is his battle against Ranaldo. After experiencing first-hand Ranaldo's valor on the battlefield, Rodamonte declares that King Sobrino had indeed spoken the truth: "Come diceva il vero il re Sobrino!" (OI 2.15.30). Rodamonte's "Io l'ho provato" (OI 2.15.29) is a direct echo of Sobrino's earlier "Io gli ho provati" (OI 2.1.51). Rodamonte, in fact, is so impressed by the truth of Sobrino's statement that he goes from one extreme to the other - whereas before he said that one should never believe another's experience, now he declares that one should always believe it: "Sempre creder si debbe a chi ha provato" (OI 2.15.30). As Rodamonte accepts this new way of learning about the world around him, he can also more accurately see himself in relation to others. His encounter with Ranaldo thus leads him to correct his perception of himself: "Io, che tutti pigliarli avea arroganza, / Assai ne ho de uno, e più che di bastanza" (OI 2.15.30).

The full transformation of Rodamonte's character comes about when he confronts Rugiero. Although Rodamonte does not find out his opponent's identity, Rugiero will change his way of seeing and his way of acting. First, Rugiero courteously takes the Christian Bradamante's place against Rodamonte when his fellow Saracen refuses to give her leave to follow the retreating Charlemagne. Then, when in the course of their battle Rodamonte loses his sword, Rugiero courteously waits for him to retrieve it rather than take advantage of the situation. Significantly, Rodamonte expresses his new evaluation of his opponent in terms of seeing: "Ben chiaramente aggio veduto / Che cavallier non è di te migliore" (OI 3.5.12). Ironically it is Rugiero, whose existence he doubted and whose importance to the invasion he dismissed, who provides Rodamonte with greater knowledge of the world and of his (smaller) place in it. It is this knowledge that leads Rodamonte to humble himself and declare unconditional obedience to Rugiero: "E sempre, quanto io possa e quanto io vaglia, / Di me fa il tuo parere in ogni banda, / Come il maggiore al suo minor comanda" (OI 3.5.13). These declarations of Rugiero's excellence and his own attitude of subservience show how his increased knowledge of the world is linked to a new way of acting. Rodamonte still thinks in extremes: the best knight he has encountered becomes the best knight tout court, and his readiness to obey is expressed with the absolutes "in ogni banda" and "sempre." Perhaps this tendency to drastic shifts in thinking, also reflected in his reassessment of Sobrino's warning in light of his encounter with Ranaldo, characterizes Rodamonte as someone who is just beginning to learn to think differently and therefore lacks subtleties. At the same time, however, Boiardo 
makes clear that Rodamonte's new estimation, while extreme, is absolutely correct. The very first verse Boiardo wrote of Rugiero had said as much: "fu d'ogni virtute il più perfetto / Di qualunque altro che al mondo si vanta" (OI 1.29.56). Rodamonte's total reversal in thinking is accompanied by an equally complete turnabout in his behavior: his arrogance has been transformed into humility. Rodamonte's itinerary of self-knowledge can be understood as a paideia, an education of the soul. ${ }^{10}$ Although the poem is interrupted before Rodamonte encounters Rugiero again and can act on his declared intentions, one could expect that the future relation between the two knights would have continued to attest to the positive effects of both Rugiero's courtesy and Rodamonte's greater self-knowledge. Charles Ross has argued that John Milton saw Rugiero as a Christ figure (385). Perhaps Rodamonte's meeting with Rugiero suggests something to that effect as well; whereas his battle against Ranaldo confirmed the rational teaching of Branzardo and Sobrino, his encounter with Rugiero harkens back to the supranatural knowledge of the King of Garamanta.

Ariosto's treatment of Rodomonte completely reverses the problem as presented by Boiardo with regards to both the acquisition of knowledge and the relation of knowledge to action. Whereas at his first appearance in the Innamorato Rodamonte did not believe anything he could not see with his own eyes, in the Furioso Rodomonte becomes the very picture of credulity. Moreover, whereas Boiardo's character would eventually profit morally when confronted by a reality that disproved his views and deflated his ego, in the Furioso, knowledge proves to be the corresponding character's undoing. Rodomonte's first error is to believe that Doralice will remain enamored of him while he spends all his time away at war. Rodomonte finds his assumption to have been misguided when Doralice chooses Mandricardo over him as her beloved. Crushed by this unwelcome reality, Rodomonte continues to think in absolutes and declares that all women are false and fickle. While this is presented as a case of disbelief (that is, he doubts the sincerity and fidelity of any woman), it is actually a case of proclaiming to have knowledge about all women without verifying his hypothesis. A single instance is sufficient to convince him that female fraud is infinite ("che de l'ascose / feminil frode sia copia infinita"). His reasoning ("or ragionando"), as the narrator comments, is without reason ("da ragion si dipartiva," 27.122; "di ragion passava il segno," 27.125).

At the council in Biserta in Innamorato 2.1, Branzardo had outlined the procedure of arriving at knowledge through reason, experience, and example. The experience and "reasoning" that has led to Rodomonte's erroneous view of women will soon find corraboration in the example of others. After abandoning Agramante, Rodamonte stops at an inn where the owner relates a misogynist tale about unfaithful women. The story of Giocondo and King Astolfo, which tells of the infidelity of every woman the two men encounter, is said to be one of the stories told to the innkeeper by Gian Francesco Valerio, an actual historical figure, who himself had 
knowledge ("sapea") of female fraud through both example and experience ("moderne istorie e antiche, / e proprie esperienze," OF 27.138). The innkeeper charges those who do not share his view to be "senza ragione" (OF 27.137) and contrasts his knowledge ("io so") with their "falsa opinione" (OF 27.135). Rodomonte believes the stories because they correspond to his emotion of anger after his "beloved" Doralice publicly declares her preference for Mandricardo. As he says to the innkeeper: "Che puoi tu farmi, / che più al presente mi diletti e piaccia, / che dirmi istoria e qualche esempio darmi / che con l'opinion mia si confaccia?" (OF 27.140). Rodomonte had arrived at the inn imitating the wandering of the unrequited Petrarchan lover ("Di pensiero in pensiero andò vagando," OF 27.133), but he seems unaware of Petrarch's warning against judgments based on emotion: "Nothing is easier than to persuade people who want to be persuaded and already believe" (73). The same warning, however, is voiced by an elderly man at the inn who, stating that we hear many things that are not true ("assai cose udimo dire / che veritade in sé non hanno alcuna," OF 28.76), maintains that anger ("ira," OF 28.78) had motivated Valerio, whose tales were based more on "opinione" than on "esperienza" (OF 28.77). Ariosto tells us that this honest and just old man had "più retta / opinion degli altri" (OF 28.76), an expression that on the one hand acknowledges all general views to be opinion without reaching the status of true knowledge, and on the other recognizes that some views are decidedly more correct than others. Following the old man's reasoning ("appresso alle ragioni," OF 28.84), he wants to provide examples to support his argument, thus reminding the reader that reason, experience, and example may support two contradictory truths and thus are no simple guarantee of trustworthiness. Rodomonte, however, refuses to even listen to examples that do not correspond to his own feelings. He is not interested in learning the truth or in acquiring greater knowledge, but only in hearing what will confirm the view he already holds. The problem that Ariosto is outlining here is the intrusive role of the emotions that prevents him from seeking the truth ("fuggia udire il vero," OF 28.84). Emotions prevent Rodomonte from gathering additional information that could lead to a more balanced judgment. Knowledge for Valerio, the innkeeper, and Rodomonte has thus been reduced to emotion-based opinion. Experience and example, in this Furioso episode, do not lead to greater knowledge, but only serve to support false beliefs.

Rodomonte's "knowledge" that all women are unfaithful is eventually belied by a new experience. When Rodomonte meets Isabella and wants to win her love, he shows his own fickleness by forgetting his previous disdain for women. Ariosto focuses on the problem of knowledge and truth throughout this episode. When Rodomonte hurls the hermit accompanying the bereaved Isabella into the air, the narrator claims not to know what became of him ("Che n'avenisse, né dico né sollo"). He then goes on 
to tell three different versions of the hermit's fall, concluding: "Di queste, qual si vuol, la vera sia: / di lui non parla più l'istoria mia" (OF 29.7). By following an acknowledgment of the narrator's limited knowledge with a proliferation of possible stories, Ariosto suggests the human propensity to substitute knowledge with imagination, leading the reader to doubt the veracity of any history.

Rodomonte's next error combines unfounded belief with the need to verify "truth" through tangible evidence. Isabella tells Rodomonte about a magic potion that will make him invulnerable. Paradoxically, however, the proof of the potion's efficiency already presupposes belief in magic, since it requires taking an axe to Isabella's neck. Her explanation to Rodomonte focuses specifically on knowledge and belief:

Acciò che paia

che mie parole al vento non ho mosse, quella che ' 1 ver da la bugia dispaia, e che può dotte far le genti grosse, te ne farò l'esperienza ancora, non ne l'altrui, ma nel mio corpo or ora. (OF 29.23)

Whereas in Innamorato 2.1 Boiardo's Rodamonte had chided the "vil gente" for believing in God out of fear, now Ariosto's Rodomonte is disposed to believe in magic out of a desire for invulnerability. This is in a sense a desire to return to the early Rodamonte's original state of mind when he had declared himself his own god. If we recall that at the time Rodamonte had stated he would only believe what was before his eyes, the full irony of the situation can be appreciated: he will believe in magic if he can see it, but he essentially needs to believe in it in order to go through with the test. Ariosto not only criticizes Rodomonte's foolishness here, but in the following canto he derides all those who believe only what they see in front of their eyes: "La sciocca turba [. . . ] non mira più lungi nè comprende di quel ch'inanzi agli occhi si ritrova" (OF 30.27).

When Rodomonte, in a drunken state, unwittingly beheads Isabella, his error is precisely that of credulity. He had put his faith erroneously both in her words and in the promise of magic to overcome the most obvious natural phenomena. When Ariosto mockingly says "Quel uom bestial le prestò fede" (OF 29.25), he is pointing to the irrational nature of Rodomonte's belief.11 With Isabella's death, once again Rodomonte's assumptions are shattered by an unwelcome reality. His response, as before, is irrational and destructive: he creates a tomb for Isabella and fights to the death all those who pass by.

Ariosto's reversal of Rodomonte's progression on the path to knowledge extends to his relation to Ruggiero. In canto 23, Rodomonte encountered Ippalca and wanted to take her horse. Upon hearing that the horse 
belonged to Ruggiero, he considered this all the more reason for seizing it: "Adunque il destrier voglio, / poi ch'a Ruggier, sì gran campion, lo toglio" (OF 23.35). Rodomonte thus ironically offends the knight to whom, at the end of the Innamorato, Rodamonte had declared unconditional obedience.

The battle between Rodomonte and Ruggiero that takes place in the final canto of the Furioso reverses their earlier battle in the Innamorato. Here we find not the Rodamonte (of OI 3.5) who confesses his inferiority to the courteous Rugiero, but the Rodamonte (of OI 2.1) who wanted to live and die as a god unto himself. When Rodomonte continues to assault Ruggiero even though his opponent has momentarily lost consciousness (OF 46.124), he thereby refuses to show the same courtesy that Rugiero had extended to Rodamonte in the earlier poem. The ending of the Furioso is followed by the saying: "Pro bono malum." Although the meaning is generally attributed (with good reason) to Ariosto's relation to the poem's dedicatee Ippolito d'Este and to court life in general, the phrase also fits Rodomonte's reversal of the earlier Rugiero's courtesy (OI 3.5).

When Rodomonte dies before the crowd gathered in Paris, he fulfills the King of Garamanta's prophecy of his death in France (OI 2.1.59) that was left unfulfilled in Boiardo's poem. Ariosto shows, moreover, that the King of Garamanta was justified in believing in what he could not see: the last "image" of Rodomonte in the poem is that of his invisible soul, now separated from its former material body, reaching the shores of Acheronte.

If one asks what Rodomonte learned in the course of Ariosto's poem, the answer is bleak. The experience of Doralice's abandonment led him to a false assumption about all women. The innkeeper's novellistic example only confirmed his negative opinion of women, which he mistook for "knowledge" but which was actually an unverified belief based on emotion. The direct experience of Isabella's faithfulness showed him the inadequacy of his vision, but his reaction to this new knowledge made him act less, not more, human. Thus, neither example nor experience nor his particular brand of reasoning led to an enlightened state of mind or to just actions. The truth did not set him free - it did not even make him wise but rather drove him to an extreme state of mind in which he acted irrationally. Rodamonte's initial road to knowledge finally came up against the dead end of death.

This reversal of Rodamonte's moral itinerary is not so much a deflation of his character per se as a questioning of the concept of knowledge. Ariosto casts doubt on both the possibility of acquiring knowledge and the positive nature of the outcome once true knowledge is acquired. A similar pattern emerges in Ariosto's treatment of the paladins Orlando and Rinaldo. Boiardo's Orlando needed to break out of a false illusion in order to regain his knightly identity. He left Charlemagne's court and headed east in search of a Saracen princess who originally planned to kill the paladins and who did not love him. He failed to comprehend Angelica as she was, and he transformed her into a creature of his imagination. Boiardo places various 
figures before him to give him greater knowledge of his error: Dragontina and her frescoed cycle of Circe and Ulysses, the perfidious Origille, the female monsters in Falerina's garden, Narcissus, and the naiads at the Laughing Stream. If Orlando would only understand that these figures, like Angelica, are false illusions, then his greater knowledge would have a positive effect on his being and his actions.

Only in the poem's final episode is there any indication of increased knowledge on Orlando's part. When he is freed from the enchantment of the Laughing Stream thanks to the knowledge (wisdom and prudence) of Fiordelisa, and the virtuous action of Brandimarte, a dwarf appears and asks the knights to accompany him on a new adventure. Orlando seems to have finally learned his lesson and he shows a new attitude of prudence. After comparing himself to a bird that has been freed from one trap and fears another, Orlando proclaims his long overdue awareness of deceptive illusion: "Ed io gabbato fui cotanto spesso, / Che, non che altrui, ma non credo a me stesso" (OI 3.7.39). He therefore does not follow the dwarf, and he heads instead to Paris to aid Charlemagne.

Whereas Boiardo suggested that the wayward paladin could recover his senses by breaking through illusion, Ariosto counters this vision by showing that it is Orlando's knowledge of Angelica's true self that finally makes him go mad. Critics have been correct in pointing out that Orlando's madness comes through reading, but the full impact of the gesture hits home only when we see this as the culmination of a series of failed readings going back to the early cantos of the Innamorato. ${ }^{12}$ Boiardo's Orlando never made the link between Angelica and the enchantress Circe (Dragontina's loggia) or the allegorical female monsters (Falerina's garden). Ariosto dispenses with the analogies and allegories and supplies Orlando directly with autobiographical and biographical, written and verbal narratives featuring Angelica herself as the main character. The stories are not didactic, but simply informative. The illusion of Angelica that Orlando had created in his mind is finally shattered through the reality of Angelica as an autonomous desiring subject. The result, however, is not a realignment of the faculties of the soul under the control of intellect and reason, but the outright disintegration of the self. As Ascoli aptly puts it: "not only is truth in crisis, truth is a crisis in itself" (326). ${ }^{13}$ Orlando's pazzia has been treated at too much length to be rehearsed again; my point here is that Ariosto turns Orlando into another example of the dangers of knowledge. Thus, the idea of an intimate tie between objective knowledge and responsible action - an idea anchored in the moral philosophy that Boiardo shared with the humanists - is no longer operative.

While in the Innamorato Rodamonte and Orlando stumbled forward on a path toward greater knowledge and virtuous action, Ranaldo, with the 
help of Merlin's fountain, already exemplified the humanist teaching on moral philosophy. Ranaldo was presented with narratives that explained how a situation of injustice was created, and his knowledge of events allowed him to act virtuously to bring about a just resolution. Knowledge was translated into ethical action as Ranaldo: 1) heard a story explaining the system of organized murder at Castle Cruel and then wiped out the evil custom, 2) read the story of the murder of Albarosa and then punished the guilty Truffaldino, and 3) heard about the rivalry turned friendship of Prasildo and Iroldo and then saved those knights from imminent death. Ranaldo thus lives out the moral philosophy which inextricably links knowledge, virtue, and action.

Ariosto initially places his Rinaldo in this same role in the Ginevra episode, but later in the poem he uses him as a reader to present a very different view of knowledge and its uses. Rinaldo hears two novellas while traveling along the Po river valley on his way toward Lipadusa. Like the reference to the historical figure Valerio in Rodomonte's episode of the inn, here too historical reality mixes with the poem's fiction as Rinaldo passes right through Estense territory. This lack of clear demarcation between the fictional and the factual brings these episodes a little closer to the real-life situation of the reader.

In the context of the first novella, Rinaldo is given the chance to gain knowledge about his wife's chastity or infidelity by drinking from a magic chalice. ${ }^{14}$ His host vividly underlines the separation between knowledge and belief in the following two verses: "Se vuoi saper se la tua sia pudica / (come io credo che credi, e creder déi)" (OF 42.102). Rinaldo, however, realizes that this knowledge can be dangerous: "quanto fosse periglioso il caso / a porvi i labri, col pensier discorse" (OF 42.104). He therefore refuses to drink from the chalice, preferring "belief" over certain knowledge of his wife's chastity. Rinaldo states his reply in terms of accepting human limitations: "Non so s'in questo io mi sia saggio o stolto / ma non vo' più saper, che mi convegna" (OF 43.7). Further expanding his reasoning, he has recourse to no less than the tree of knowledge in Genesis: "che tal certezza ha Dio più proibita / ch'al primo padre l'arbor de la vita" (OF 43.7). Knowledge is thus equated with transgression. Rinaldo's new aversion to knowledge thus leads him to equate willful ignorance of his wife's possible infidelity with the bliss of the garden of Eden, as though closing his eyes to reality could allow him to create his own terrestrial paradise. ${ }^{15}$ Indeed, rather than "love of wisdom," Rinaldo is advocating a "love of ignorance," and thereby preserving his own mental well-being.

The novellistic "example" about adultery that follows the proposed test seems to confirm the sagacity of Rinaldo's refusal, since the moral that Rinaldo draws from it is the inevitability of corruption and thus the need to avoid putting one's virtue to the test. The host tells how he had actually led his wife to adultery by testing her virtue. Rinaldo's response to the story is to question the host's own steadfastness: "Se te 
altretanto avesse ella tentato, / non so se tu più saldo fossi stato" (OF 43.49).

The second story told to Rinaldo on his journey is pointedly referred to an esempio (OF 43.70), thus recalling the novella's didactic potential. A boatman tells of a woman who is accused by her husband of having been seduced by the allure of riches and who gets the upper hand when her husband falls into an even more repugnant state by allowing himself to be sodomized by a grotesque brute. Unlike the earlier Ginevra episode, here everyone is guilty. This example presents a picture of a fallen humanity with no hope of redemption and no possibility for the reader to intervene to bring about justice. Indeed, Rinaldo, laughing at the story, limits himself to praising the wife and blushing for the husband (OF 43.144). Ronald Martinez notes "the emphasis throughout the whole episode on consciousness of faults in the self" as he argues for "the morally therapeutic dimensions of Rinaldo's journey" $(25,30) .{ }^{16}$ I would propose instead that this increased consciousness of faults reveals the author's profound cynicism regarding human nature without offering any hope for improvement. Rinaldo's praise of Argia ("Rinaldo Argia molto lodò," OF 43.144) for throwing her husband into a lower moral ditch than the one into which she herself had fallen is a far cry from Ranaldo's expression of praise for Iroldo and Prasildo's reciprocal benevolent actions and his desire to risk his life to participate in their ideal friendship. The moral virtues sustaining Boiardo's poem have been completely redefined. Prudence, as the Po journey's first novella and surrounding narrative context show, no longer means acting according to the dictates of reason, but rather choosing a veneer of false seeming over an unpleasant truth. Wisdom, in the second novella, has lost its ethical purpose and has been turned into the cleverness of a wife setting a trap for her husband. Finally, justice no longer entails combatting evil, but simply proving to our neighbor (or spouse!) that he is more degenerate than we are.

The reversal in Rinaldo's attitude from civic-minded engagement to a cynical passivity nullifies his role as a reader who interprets a story and then acts on his knowledge. On the contrary, the idea of bringing about a change for the better in a morally corrupt universe motivated solely by self-interest seems hardly a viable one, and we are at a loss to find an alternative response to Rinaldo's bemused cynicism.

If Ariosto's Orlando provides a negative parallel to Rodomonte, since each is devastated by unwelcome knowledge about his "beloved," in the concluding cantos Rinaldo comes to function as a positive contrast to both, albeit in an insidiously ironic way. He knows ahead of time that knowledge can make one insane, and he prefers to live with illusion. In Ariosto's fictional world not only does false opinion masquerade as knowledge, but even in cases in which objective knowledge is possible, it is not necessarily desirable. The world is so corrupt, and human nature responds so destructively to unpleasant realities, that it is sometimes better not to know the 
truth at all. Reflecting Ariosto's own personal situation and the general state of affairs in the Italian peninsula in the early sixteenth century, the Furioso's treatment of Rodomonte, together with that of Orlando and Rinaldo, breaks the Innamorato's link between knowledge and ethical action and offers little hope to its readers for a better future.

JO ANN CAVALLO

Columbia University

\section{NOTES}

${ }^{1}$ For a concise and useful overview of Renaissance theories of knowledge, see Popkin. Cassirer, Copleston, and Kristeller offer diverse accounts of Renaissance philosophy that nevertheless frequently address questions of knowledge.

2I cite from Bruscagli's widely available paperback edition of the poem, but I also consulted Tissoni Benvenuti and Montagnani's recent critical edition. While the language of the critical edition is more archaic, there were no differences of a semantic nature for any of the passages cited in this essay.

${ }^{3}$ As Murrin has noted, the failure of Agramante's invasion will confirm the validity of Sobrino's analysis (110).

${ }^{4}$ Boiardo's understanding of a close link between wisdom and prudence comes through in his translation of Herodotus in which he interchanges the terms, translating "vir sapiens" as "uno omo di estimata prudentia," thus conveying more forcefully the idea of knowledge related to correct action (24r).

${ }^{5}$ For the discussion of prudence and wisdom, see page 190.

${ }^{6}$ Rice warns that these ideas are not widespread in fifteenth-century Italy (49). However, they would have been available to the Ferrarese court since the time of Guarino da Verona, and Boiardo's poem as a whole is indebted to the moral philosophy of civic humanism. See Cavallo and Cossutta.

${ }^{7}$ The Project Gutenberg Etext of Theaetetus, trans. Benjamin Jowett.

${ }^{8}$ This trajectory of knowledge is first explored in Nicholas of Cusa, De docta ignorantia (On Learned Ignorance, 1440), available in translation as Of Learned Ignorance: A Translation and Appraisal of the De Docta Ignorantia, and later developed in his other speculative works, especially De coniecturis (On Conjectures, c. 1443), Apologia doctae ignorantiae (Apology of Learned Ignorance, 1449), and De visione dei (On the Vision of God, 1453).

${ }^{9}$ Alexandre-Gras notes Rodamonte's positive transformation, although she does not discuss it in terms of knowledge but links it instead to the general civilizing process that Boiardo's pagan knights undergo in the course of the poem.

${ }^{10} 0_{\mathrm{I}}$ am using the term as outlined by Jaeger.

${ }^{11}$ Although Benson develops her argument along different lines, her following comment regarding Rodomonte is a propos here: "Experience corrects his opinion of women and leads him to appreciate the truth of the old man's concept" (107). See also Weaver 396-98. 
${ }^{12}$ Arguing that Ariosto's poem demonstrates the dangers of knowledge, especially in the area of love, Weaver writes: "Orlando è un lettore preparato, sa leggere bene, perfino l'arabo, e per aver saputo troppo, anche se involontariamente, è distrutto" (395).

${ }^{13}$ For a different take on the problem of knowledge and ignorance in the Furioso, see Ascoli 321-31.

${ }^{14}$ For a close reading of this episode see Santoro who, however, reads Rinaldo's refusal to drink as a warning of the limits of the possibility of knowledge in the face of an ever-changing reality (16). See also Martinez (25), Sherberg (43-89), and Weaver (400) who reads Rinaldo's refusal to know too much about his spouse as a counterexample to the pazzia that Orlando and Rodomonte undergo upon learning an unpleasant truth about their beloved.

${ }^{15}$ Benson writes: "Rinaldo develops the analogy to draw a parallel between the consequences of knowledge in Adam's case and in the case of the inquiring husband and reveals the misogynist audacity of his analogy and the particular limits of his own philosophy." She continues: "He suggests that, in both the case of the apple and of the wife, God forbade knowledge to man because it would bring man unhappiness" (112).

${ }^{16}$ Martinez reads Rinaldo's story (from the stream of disamore to Anselmo's tale) as a process of "reeducation" after he falls in love with Angelica (25). By comparing Rinaldo's new attitude to his role as a civic-minded reader before his enamorment, I view the events as part of a more negative process.

\section{WORKS CITED}

Alexandre-Gras, Denise. "Le jardin enchanté dans le roman chevaleresque italien." Le Paysage à la Renaissance. Ed. Yves Giraud. Fribourg, Switzerland: Editions Universitaires, 1985. 147-56.

Ariosto, Lodovico. Orlando furioso. Ed. Marcello Turchi. 2 vols. Milan: Garzanti, 1974. Aristotle. Metaphysics. Trans. W. D. Ross. Oxford: Clarendon, 1924.

. The Nicomachean Ethics. Trans. J. A. K. Thomson. 1953 Great Britain: Penguin, 1959.

Ascoli, Albert Russell. Ariosto's Bitter Harmony: Crisis and Evasion in the Italian Renaissance. Princeton: Princeton UP, 1987.

Benson, Pamela Joseph. The Invention of the Renaissance Woman. University Park, PA: Pennsylvania State UP, 1992.

Boiardo, Matteo Maria. L'Inamoramento de Orlando. Ed. Antonia Tissoni Benvenuti and Cristina Montagnani. Opere. Vols. 1-2. Milan: Ricciardi, 1999.

. Orlando innamorato. Ed. Riccardo Bruscagli. Turin: Einaudi, 1995. 2 vols.

, trans. Delle guerre de greci \& de persi, by Herodotus. Venice: Bernardino de Bindoni, 1539.

Cassirer, Ernst. The Individual and the Cosmos in Renaissance Philosophy. Trans. Mario Domandi. Philadelphia: U of Pennsylvania P, 1979.

Cavallo, Jo Ann. Boiardo's Orlando innamorato: An Ethics of Desire. Rutherford, NJ: Fairleigh Dickinson UP, 1993.

Cossutta, Fabio. Gli ideali epici dell'Umanesimo e l'Orlando innamorato. Rome: Bulzoni, 1995. 
Copleston, Frederick, S. J. Late Medieval and Renaissance Philosophy. A History of Philosophy. Vol. 3. New York: Doubleday, 1993.

Jaeger, Werner. Paideia: The Ideals of Greek Culture. Trans. Gilbert Highet from 2nd German ed. New York: Oxford UP, 1945. 3 vols.

Kristeller, Paul Oskar. Renaissance Thought and Its Sources. Ed. Michael Mooney. New York: Columbia UP, 1979.

Martinez, Ronald L. "Two Odysseys: Rinaldo's Po Journey and the Poet's Homecoming in Orlando furioso." Renaissance Transactions: Ariosto and Tasso. Ed. Valeria Finucci. Durham, NC: Duke UP, 1999. 17-55.

Murrin, Michael. “Agramante's War.” Annali d'Italianistica: Pulci \& Boiardo 1 (1983): 107-28.

Nicholas of Cusa. Of Learned Ignorance: A Translation and Appraisal of the De Docta Ignorantia. Trans. J. Hopkins and A. J. Banning. Minneapolis, 1981.

Petrarca, Francesco. "On His Own Ignorance and That of Many Others." The Renaissance Philosophy of Man. Ed. Ernst Cassirer, Paul Oskar Kristeller and John Herman Randall, Jr. Chicago: U of Chicago P, 1948. 47-133.

Plato. The Project Gutenberg Etext of Theaetetus. Trans. Benjamin Jowett. Internet site: ftp://ibiblio.org/pub/docs/books/gutenberg/etext99/thtus10.txt.

Popkin, Richard H. "Theories of Knowledge." The Cambridge History of Renaissance Philosophy. Ed. Charles B. Schmitt and Quentin Skinner. Cambridge, UK: Cambridge UP, 1988. 668-84.

Rice, Eugene F., Jr. The Renaissance Idea of Wisdom. 1958c. Westport, CT: Greenwood, 1973.

Ross, Charles. "False Fame in Paradise Regained: The Siege of Albraca." Milton and Italy: Contexts, Images, Contradictions. Binghamton: MRTS, 1991. 381-403.

Santoro, Mario. "La prova del 'nappo' e la cognizione ariostesca del reale." Esperienze letterarie (1976): 5-24.

Sherberg, Michael. Rinaldo: Character and Intertext in Ariosto and Tasso. Stanford French and Italian Studies 75. Saratoga, CA: Anma Libri, 1993.

Weaver, Elissa. "Lettura dell'intreccio dell'Orlando furioso: il caso delle tre pazzie d'amore." Strumenti critici 11.3 (1977): 384 406. 